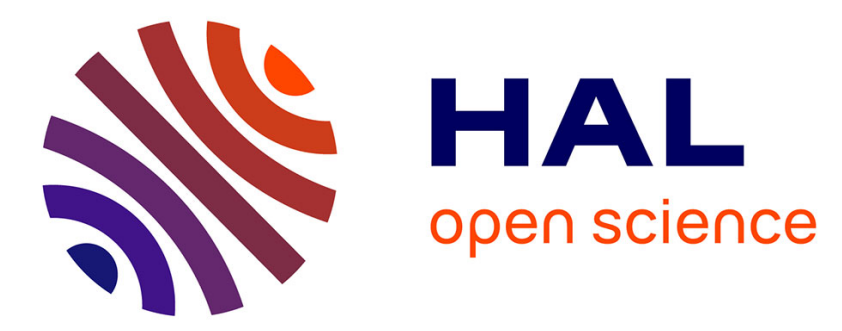

\title{
Plasma $\beta$-amyloid peptides in canine aging and cognitive dysfunction as a model of Alzheimer's disease
} Ángela González-Martínez, Belén Rosado, Pedro Pesini, María-Luisa Suárez, Germán Santamarina, Sylvia García-Belenguer, Ainara Villegas, Inmaculada Monleón, Manuel Sarasa

\section{To cite this version:}

Ángela González-Martínez, Belén Rosado, Pedro Pesini, María-Luisa Suárez, Germán Santamarina, et al.. Plasma $\beta$-amyloid peptides in canine aging and cognitive dysfunction as a model of Alzheimer's disease. Experimental Gerontology, 2011, 10.1016/j.exger.2011.02.013 . hal-00701267

\section{HAL Id: hal-00701267 https://hal.science/hal-00701267}

Submitted on 25 May 2012

HAL is a multi-disciplinary open access archive for the deposit and dissemination of scientific research documents, whether they are published or not. The documents may come from teaching and research institutions in France or abroad, or from public or private research centers.
L'archive ouverte pluridisciplinaire HAL, est destinée au dépôt et à la diffusion de documents scientifiques de niveau recherche, publiés ou non, émanant des établissements d'enseignement et de recherche français ou étrangers, des laboratoires publics ou privés. 


\section{Accepted Manuscript}

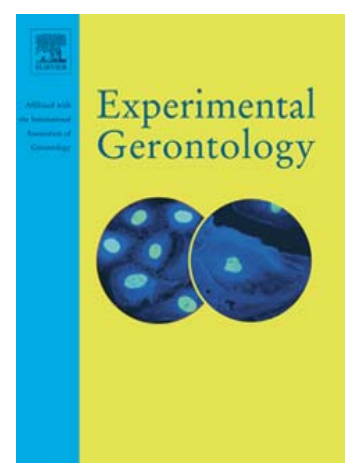

Plasma $\beta$-amyloid peptides in canine aging and cognitive dysfunction as a model of Alzheimer's disease

Ángela González-Martínez, Belén Rosado, Pedro Pesini, María-Luisa Suárez, Germán Santamarina, Sylvia García-Belenguer, Ainara Villegas, Inmaculada Monleón, Manuel Sarasa

PII: $\quad$ S0531-5565(11)00063-5

DOI: $\quad$ doi: $10.1016 /$ j.exger.2011.02.013

Reference: $\quad$ EXG 8864

To appear in: $\quad$ Experimental Gerontology

Received date: 16 December 2010

Revised date: $\quad 22$ February 2011

Accepted date: $\quad 22$ February 2011

Please cite this article as: González-Martínez, Ángela, Rosado, Belén, Pesini, Pedro, Suárez, María-Luisa, Santamarina, Germán, García-Belenguer, Sylvia, Villegas, Ainara, Monleón, Inmaculada, Sarasa, Manuel, Plasma $\beta$-amyloid peptides in canine aging and cognitive dysfunction as a model of Alzheimer's disease, Experimental Gerontology (2011), doi: $10.1016 /$ j.exger.2011.02.013

This is a PDF file of an unedited manuscript that has been accepted for publication. As a service to our customers we are providing this early version of the manuscript. The manuscript will undergo copyediting, typesetting, and review of the resulting proof before it is published in its final form. Please note that during the production process errors may be discovered which could affect the content, and all legal disclaimers that apply to the journal pertain. 
Plasma $\beta$-amyloid peptides in canine aging and cognitive dysfunction as a model of Alzheimer's disease

Ángela González-Martínez ${ }^{\mathrm{a}}$, Belén Rosado ${ }^{\mathrm{b}}$, Pedro Pesinic*, María-Luisa Suárez ${ }^{\mathrm{a}}$, Germán Santamarina $^{\mathrm{a}}$, Sylvia García-Belenguer ${ }^{\mathrm{b}}$, Ainara Villegas ${ }^{\mathrm{b}}$, Inmaculada Monleón $^{\mathrm{c}}$ and Manuel Sarasa ${ }^{\mathrm{c}}$.

a. Departamento de Ciencias Clínicas Veterinarias, Facultad de Veterinaria de Lugo, Universidad de Santiago de Compostela, 27002 Lugo, Spain.

b. Departamento de Patología Animal, Facultad de Veterinaria, Universidad de Zaragoza, 50013 Zaragoza, Spain.

c. Araclon Biotech Ltd, 50004 Zaragoza, Spain.

NOTE: The first two authors contributed equally to this work.

* Corresponding author.

Pedro Pesini

Araclon Biotech Ltd.

Franz Schubert 2, $3^{\mathrm{a}}$ planta,

(Clínica Montecanal)

50012 Zaragoza, Spain.

Tel.: +34 876241666 .

fax: +34976020011.

E-mail address: pedropesini@ araclon.com 


\begin{abstract}
Aging dogs naturally demonstrate cognitive impairment and neuropathology that models early Alzheimer's disease (AD). In particular, there is evidence that canine cognitive dysfunction syndrome (CDS) in aged dogs is accompanied by cortical deposition of $A \beta$ peptides and neurodegeneration. Plasma $A \beta$ levels have been examined in humans as putative biomarkers for $\mathrm{AD}$, but to date, no similar studies have been conducted for canine dementia. The aim of the present study was to assess plasma $A \beta 1-42$ and $A \beta 1-40$ levels in a blind study using pet dogs that were either successfully aging or exhibiting CDS. The severity of cognitive impairment was assessed using an owner-based questionnaire. On average, young dogs presented significantly higher plasma levels of $A \beta 1-42$ and $A \beta 1-40$ than aged, cognitively unimpaired dogs. Notably, among aged dogs, the levels of $A \beta 1-42$ and the $A \beta 42 / 40$ ratio were significantly higher in those showing mild cognitive impairment than in either cognitively unimpaired or severely affected dogs. These results suggest that increased plasma A $\beta 1-42$ levels and A $\beta 42 / 40$ ratio could be a biomarker for canine cognitive dysfunction, which is considered an excellent natural model of early AD.
\end{abstract}

Keywords: Amyloid-beta protein; plasma; Alzheimer's disease; animal behavior; canine; ELISA; neurodegeneration; brain aging. 


\section{Introduction}

Dogs may naturally suffer age-related cognitive deficits that parallel several key aspects of early Alzheimer's disease (AD). There is evidence of $\beta$-amyloid $(A \beta)$ deposits and amyloid angiopathy in the brain of aged dogs $[1,2]$. Furthermore, the extent of $A \beta$ deposition in the cerebral cortex has been shown to correlate with declines in select measures of cognitive function in aged beagle dogs and in aged pet dogs [3, 4]. Other neuropathological features of $\mathrm{AD}$, such as neurodegeneration and oxidative damage, have also been reported in aged dogs [4-13]. Furthermore, from the molecular perspective, it has been found extensive homology for the canine $A \beta$ (100\% similarity), its precursor protein (APP, 98\%), and the enzymes for APP processing (92-100\%) with their human counterparts $[14,15]$. Altogether, these data suggest the dog as an appropriate natural model for studying the biology of AD [16].

Research on the canine model of $\mathrm{AD}$ has been extensively conducted using laboratory beagle dogs rather than pet/companion dogs. However, the latter population may offer additional contributions to the investigation of $\mathrm{AD}$ because these dogs share a common environment with humans and, therefore, encounter similar environmental stressors during the aging process [17]. Cognitive dysfunction syndrome (CDS) in elderly pet dogs is characterized by behavioral and cognitive deficits that fall into four main categories: sleep-wake cycle, social interaction, housetraining, and orientation [18, 19]. Owner-based questionnaires show that CDS may affect more than $22 \%$ of geriatric dogs, and prevalence and severity increase strikingly with age [20, 21]. These data highlight the relevance of this canine syndrome, not only for research purposes as a model for $\mathrm{AD}$ but also plainly from a veterinary clinical point of view.

Increasingly, it appears that early diagnosis of $\mathrm{AD}$, even at pre-symptomatic stages, is essential for effective therapeutic intervention. Therefore, there is an urgent need for 
reliable biomarkers that can detect the onset of brain amyloid pathology before irreversible neurodegeneration has taken place. Plasma $A \beta 1-42$ and $A \beta 1-40$ peptides have been proposed as non-invasive peripheral biomarkers to distinguish between cognitively healthy people and patients with mild cognitive impairment (MCI) with a high degree of sensitivity and specificity [22-31]. However, considerable controversy remains in the field, and it is still too early to clearly establish the role of $A \beta$ blood tests as a diagnostic tool for MCI and AD [32-39]. To date, no similar studies have been performed in pet dogs.

The aim of the present study was to assess the plasma levels of $A \beta 1-40$ and $A \beta 1-42$ in pet dogs with and without CDS. To this end, four groups of privately owned dogs were considered: young, middle-aged, cognitively unimpaired aged, and cognitively impaired aged animals. Taking into account our preliminary results in human patients, we hypothesized that plasma $\mathrm{A} \beta$-peptides levels would differ among the different groups of animals and would relate to the presentation of cognitive dysfunction in the aged groups [40].

\section{Materials and methods}

\subsection{Study population}

Two veterinary teaching hospitals (Universidad de Santiago de Compostela and Universidad de Zaragoza, Spain) contributed to the collection of cases. Dogs were recruited from animals in these hospitals' populations that were not referred for behavioral consultations at the time of admission; they were all small to medium-sized dogs usually living with their owners (i.e., pets). There were no selection criteria regarding neuter status, but the groups were sex-balanced (Table 1). 
In total, 88 animals were enrolled in the study. The subjects were sorted into four groups: i) young ( $\mathrm{YG}, 1-4$ years of age, $\mathrm{n}=9$ ), ii) middle aged (MA, 5-8 years of age, $n=10)$, iii) cognitively unimpaired aged (CU, $\geq 9$ years of age, $n=31)$, and iv) cognitively impaired aged $(\mathrm{CI}, \geq 9$ years of age, $\mathrm{n}=38)$. The animals were treated according to the European and Spanish legislations on animal handling (86/609/EU, Real Decreto 1201/2005) and the experiments and procedures were approved by the Ethical Committees of the University of Santiago and Zaragoza.

\subsection{Medical assessment}

Prior to inclusion in the study for $A \beta$ peptides analysis, all dogs were screened by routine physical and neurological examination, complete blood count, serum biochemistry and thyroid hormone measurement, and urinalysis when needed. Animals with primary organ system failure (other than brain degeneration), hypothyroidism, untreated Cushing's syndrome and seriously affected mobility were excluded from the study. Animals with severe loss of visual capacity were also excluded.

\subsection{Cognitive assessment}

Classification of cognitive status was carried out using an owner-based observational questionnaire (see Table 2). The design of the questionnaire was based on previously published models [3, 18-20] and included a number of behavioral and cognitive items grouped into four categories: (a) sleep-wake cycle, (b) socio-environmental interaction, (c) housetraining and commands, and (d) disorientation. The questionnaires were administered to the owners by two doctors in veterinary medicine (DVM) who specialize in behavior (AG-M and BR). The owners of the aged dogs were asked to compare the dog's present behavior to its behavior prior to 9 years of age, when the dog was a younger adult. After matching the affected items (Yes or No answer), the owner 
was asked to grade the severity of the impairment for each category using a five-point scale $(0=$ non-impaired; $4=$ severely impaired $)$.

A dog was considered to be impaired in a category if at least one item was affected and that category scored $\geq 1$ points. A dog was considered cognitively impaired when two or more categories were impaired and the total dysfunction score (TDS, the sum of scores attributed by the owner to each of the four categories) was $\geq 2$ points. A score of 2 to 5 points was described as mild cognitive impairment $(\mathrm{mCI})$ and $\geq 6$ points as severe cognitive impairment (sCI). Simultaneously, using the information obtained during the screening, the researchers filled out the canine dementia questionnaire published by Rofina et al. [4] for every animal. The dementia score obtained from that questionnaire is referred to hereafter as the Rofina dysfunction score (RDS).

\subsection{Blood sampling and $A \beta$ peptide analysis}

Blood samples $(5 \mathrm{ml})$ were collected from the jugular vein into polypropylene vials containing EDTA and a protease inhibitor cocktail (CompleteMini, Roche); they were centrifuged $\left(2500 \mathrm{~g}, 4^{\circ} \mathrm{C}, 15 \mathrm{~min}\right)$, aliquoted and coded without any reference to the age or cognitive state of the animals. The aliquots of plasma were immediately frozen at $80^{\circ} \mathrm{C}$ and sent to the Araclon laboratory. $\mathrm{A} \beta 1-42$ and $\mathrm{A} \beta 1-40$ were measured in plasma using two specific ELISA sandwich kits (ABtest 40 and ABtest 42; Araclon Biotech Ltd., Zaragoza, Spain). Each sandwich kit is composed of an N-terminal A $\beta$-binding capture antibody and a C-terminal $A \beta 1-40$ or $A \beta 1-42$ binding detection antibodies, respectively. The samples and peptide standards were always assayed in triplicate. To test the reproducibility of the analysis, the ELISA was repeated on two different days. Average coefficients of variation $(\mathrm{CV})$ between the two assays were $7.84 \%$ for A $\beta 1-42$ and $13.07 \%$ for $A \beta 1-40$. Furthermore, comparing the series of measurements using the Wilcoxon test indicated that the measurements of $A \beta 1-42$ levels, $A \beta 1-40$ levels, and the 
A $\beta 42 / 40$ ratio did not differ significantly between the two assays $(p=0.472, p=0.162$, and $p=0.277$, respectively). Therefore, the averaged data from the two assays was used for further statistical analysis.

An additional 3-ml blood sample from each animal was collected for cell count and serum clinical biochemistry.

\subsection{Statistical analysis}

The plasma concentration of $A \beta 1-42, A \beta 1-40$ and the $A \beta-42 / 40$ ratio were defined as dependent variables whose group mean values were compared using Mann-Whitney U tests. Correlations were analyzed using Spearman's rank correlation tests. Chi-square tests were used to compare the distribution of categorical demographic or cognitive variables among groups. The differences in serum biochemical parameters were assessed either by ANOVA or Kruskal-Wallis test, if the parameter distribution was parametric or non-parametric, respectively. Receiver operating characteristic (ROC) curves were used to assess the accuracy of the dependent variables in classifying the presence versus absence of cognitive impairment. Calculations were carried out using the statistical program SPSS 15.0 for Windows (SPSS, Inc., Chicago, IL, USA), and $p \leq$ 0.05 denoted statistical significance.

\section{Results}

\subsection{Demographic data}

Demographic information for each group is shown in Table 1. Non-significant differences were found for sex, reproductive status, and weight or body condition among groups. Moreover, the CU and CI groups did not differ significantly in age. The CU group showed significantly higher serum albumin concentrations than the CI group $(4.12 \mathrm{~g} / \mathrm{dl} \pm 0.52$ vs $3.74 \mathrm{~g} / \mathrm{dl} \pm 0.56$, respectively; $p=0.01)$. This difference was 
considered clinically irrelevant, and there were no other biochemical or hematological differences between the aged groups (data not shown).

\subsection{Clinical diagnosis of canine CDS}

Table 2 shows the frequency distribution of impaired behavioral categories and items in each group. The proportion of dogs with affected items in the CI group was significantly higher than in the CU group for all items except for "vocalizing at night" and "decrease in recognizing familiar people". Obviously, the CI group showed significantly higher TDS than the CU group $(6.08 \pm 3.26$ vs $0.35 \pm 0.48$, respectively; $p$ $<0.001)$ and the same occurred for the RDS $(9.79 \pm 6.70$ vs $1.23 \pm 1.91$, respectively; $p$ $<0.001)$. Furthermore, TDS was strongly correlated with the number of affected items $(r=0.91, p<0.001)$ and RDS $(r=0.89, p<0.001)$ in the aged groups $(\mathrm{CU}$ and $\mathrm{CI})$.

\subsection{Plasma $A \beta 1-40$ and $A \beta 1-42$}

The mean $A \beta$ peptide concentrations and $A \beta 42 / 40$ ratio values for each group are shown in Table 3. The levels of A $\beta 1-42$ and $A \beta 1-40$ were correlated with each other across the study groups $(r=0.68 ; p<0.001)$, but they did not correlate with any hematological or serum biochemical parameters (data not shown). The plasma concentration of $A \beta$ peptides, particularly $A \beta 1-42$, varied considerably between dogs, even within a given group, as denoted by the high standard deviations (SD).

The highest $A \beta 1-42, A \beta 1-40$ peptide concentrations and $A \beta 42 / 40$ ratio were found in the youngest group (YG). Thus, the $\mathrm{YG}$ and $\mathrm{CU}$ groups differed significantly for both $A \beta$-peptides and $A \beta 42 / 40$ ratio. The concentrations of $A \beta 1-42$ and the $A \beta 42 / 40$ ratio in the MA group were between those in the $\mathrm{YG}$ and $\mathrm{CU}$, but the differences did not reach statistical significance (Fig 1A). 
Within the aged animals, it was found that $\mathrm{A} \beta$ plasma levels differed with cognitive status. Thus, the CI group showed significantly higher $A \beta 1-42$ levels and $A \beta 42 / 40$ ratio, but not A $\beta 1-40$ levels, than the CU group (Table 3). Nevertheless, because of the wide dispersion of the measurements, individual values for these two parameters showed considerable overlap between the two groups. This overlap compromised the capability of the tests to discriminate between $\mathrm{CU}$ and $\mathrm{CI}$ animals, with an area under the ROC curve $($ AUC $)<0.67$ for the three parameters, and only statistically significant for A $\beta 1$ $42(p=0.02)$. Furthermore, measurements of $A \beta 1-42$ levels, $A \beta 1-40$ levels or $A \beta 42 / 40$ did not correlate with the any dementia score in the aged groups (data not shown). However, when we split the CI group, the severely impaired animals (sCI, $\mathrm{n}=17$ ) showed a significantly lower $A \beta 1-42$ level and $A \beta 42 / 40$ ratios than the mildly impaired animals ( $\mathrm{mCI}, \mathrm{n}=21$, Table 4). Moreover, the average $\mathrm{A} \beta 1-42$ levels and $\mathrm{A} \beta 42 / 40$ ratio were 2.5 times and 1.8 times greater, respectively, in the $\mathrm{mCI}$ than in the aged unimpaired CU group $(p<0.01)$ (Table 4, Fig 1B). In concordance with these results, the ability of the $A \beta 1-42$ level and the $A \beta 42 / 40$ ratio, but not the $A \beta 1-40$ level, to discriminate between $\mathrm{CU}$ and $\mathrm{mCI}$ animals (instead of between $\mathrm{CU}$ and $\mathrm{CI}$ groups) substantially improved $(\mathrm{AUC}=0.78 ; p<0.001)($ Fig 2A-C). Notably, when CU and $\mathrm{mCI}$ animals were plotted together (without the sCI), both the $\mathrm{A} \beta 1-42$ level and the A $342 / 40$ ratio showed a weak but significant correlation with TDS $(r=0.44$ and 0.47 , respectively; $p \leq 0.001$ ), total number of positive items ( $r=0.42$ and 0.53 , respectively; $p \leq 0.002)$ and RDS ( $r=0.37$ and 0.41 , respectively; $p \leq 0.007)$.

\section{Discussion}

\subsection{Plasma $A \beta 1-40$ and $A \beta 1-42$ in relation to age and cognitive dysfunction.}

In the present study, classification of cognitive status was carried out using an ownerbased questionnaire after ruling out other medical causes of dementia-like changes. This 
questionnaire included four behavioral categories that were graded in severity by the owner according to a five-point scale to obtain a total cognitive dysfunction score (TDS). Owner-based questionnaires, including psychometric scales, have already been used for measuring and phenotyping behavior in dogs [3, 18-20]. The most affected categories in our geriatric animals were "sleep/wake cycle" and "socio-environmental interactions," but cognitively impaired dogs were significantly more frequently affected in all categories and in the vast majority of items than the healthy aged group. The number of affected items was strongly related to the above-mentioned TDS, suggesting that the severity assessment carried out by the owner is greatly dependent on the number of contexts in which the dog shows impairment.

The two groups of aged animals were highly homogeneous regarding age, sex and reproductive status distributions, weight or body condition. Furthermore, there were not any significant hematological or biochemical differences between these two aged groups except for serum albumin that appeared slightly increased in the CU with respect to the CI group. It has been reported that mild decreases of serum albumin is related to an increased risk of mortality, disability, sarcopenia and frailty in people over 65 years [41]. However, this type of information is scarce in veterinary practice. Recently it has been reported an increasing mortality risk in dogs as albumin decreased from 40 to 15 g/L (i.e., a very substantial decrease) [42]. However, it is important to note that this study was carried out in hospitalized dogs, not in the normal population. The subtle serum albumin difference between our two aged groups $(4.12 \mathrm{~g} / \mathrm{dl} \pm 0.52$ in $\mathrm{CU}$ vs 3.74 $\mathrm{g} / \mathrm{dl} \pm 0.56$ in the $\mathrm{CI})$ was considered clinically irrelevant.

The primary objective of the present study was to analyze plasma levels of $A \beta 1-42$ and A $\beta 1-40$ peptides in relation to age and cognitive dysfunction in pet dogs. The concentrations of these two $A \beta$ isoforms were correlated, and $A \beta 1-40$ levels were 
higher than $A \beta 1-42$ levels in all the study groups. Both these features agreed with the results reported in the majority of similar studies conducted in humans $[25,26,28,30$, 43].

We found that plasma $A \beta$ peptides levels tended to decrease with age in cognitively intact dogs (i.e., in young, middle-aged and cognitively unimpaired aged groups). In particular, dogs less than 4 years old showed significantly higher A $\beta 1-42$ and A $\beta 1-40$ levels, as well as higher $\mathrm{A} \beta 42 / 40$ ratio values, than those more than 9 years old. A recent study carried out in healthy beagles (4-16 years old) showed that $A \beta 1-42$, but not A $\beta 1-40$, levels decrease slightly in cerebrospinal fluid (CSF) as brain amyloid deposition increases with age [44]. Our results suggest that the observed reduction of plasma $A \beta 1-42$ and $A \beta 1-40$ concentrations in cognitively unimpaired aged dogs might also be a consequence of increasing brain amyloid deposition, although a decreased production of mentioned peptides could not be excluded. In contrast, higher A $\beta 1-42$ plasma levels and $A \beta 42 / 40$ ratio were detected in dogs suffering from CDS when compared with cognitively unimpaired dogs. Thus, it appeared that the onset of the clinical condition was accompanied by an increase in $A \beta 1-42$ production that might reverse the decrease in $A \beta$ peptides levels observed in successful aging. These results are consistent with numerous studies on AD that have reported a relationship between elevated plasma $A \beta$ peptide levels and the disease in humans [22-31]. From those studies, it is becoming increasingly clear that the elevation in $A \beta$ blood levels is an early event that could precede the onset of cognitive symptoms and increase the risk of developing AD [45-49]. Notably, when we separated dogs with a CDS diagnosis into two subgroups according to the severity of the syndrome (i.e., $\mathrm{mCI}$ and $\mathrm{sCI}$ ), new differences emerged. Thus, the mCI animals showed significantly higher A $\beta 1-42$ levels and $\mathrm{A} \beta 42 / 40$ ratio values than the sCI dogs and the $\mathrm{CU}$ dogs; no significant differences 
appeared between these latter groups. In contrast, plasma $A \beta 1-40$ levels did not change according to diagnosis or severity of CDS. Again, these results were similar to studies reporting that a faster cognitive decline and/or progression of $\mathrm{AD}$ were accompanied by decreases in plasma $\mathrm{A} \beta 1-42[22,24,26,28,29,31]$. In a pilot study including 40 participants, we recently found that human plasma $A \beta 1-42$ and $A \beta 1-40$ concentrations were significantly higher in MCI patients than in non-demented controls. Furthermore, in that study, we observed that, although the different markers of the $A \beta$ pool in blood did not vary significantly between MCI and AD groups, they tended to decrease in the AD patients with the lower MMSE [40]. The amyloid hypothesis states that AD pathology starts when $A \beta$ peptides, particularly $A \beta 1-42$, begin to aggregate and precipitate in the interstitial spaces of the brain. In this situation, diffusion of brain $A \beta$ toward the ventricular system will be severely hampered, leading to a reduction in $\mathrm{A} \beta 1$ 42 levels in the CSF that has been shown to herald cognitive decline $[32,45,50,51]$. At the initial stage of the disease, probably without extensive capillary damage, the increased $\mathrm{A} \beta$ blood levels observed in humans and, in this study, in mCI dogs might reflect the increasing peptide levels in brain tissue. The subsequent drop of plasma A $\beta 1$ 42 observed in both canines and humans as the disease progresses could be related to the deposition of $\mathrm{A} \beta$ around capillaries, which would seal off the blood-brain barrier. Thus, the results of the present work revealed a similar pattern of plasma $A \beta$ changes in dogs and humans during the progression of cognitive impairment. This parallelism reinforces the similarities between canine CDS and AD and suggests that those dogs suffering mild cognitive impairment could model human MCI, whereas those displaying severe impairment could model early or mild sporadic AD. A longitudinal study (already in progress), rather than a cross-sectional approach, will help better explore these disease-related changes in plasma $A \beta$ peptides in dogs. 
Some limitations still remain regarding classification of the cognitive status in aged dogs. Notably, the available tools and criteria for diagnosis of age-associated cognitive impairment, mild cognitive impairment and dementia in canines (or other animals) are not as developed as in humans. In addition, it is possible that a CDS diagnosis in dogs could include dementias other than AD-like dementia (e.g., vascular dementia). We found that our owner-based TDS was strongly correlated with the RDS obtained with the test of Rofina et al. [4]. In RDS, the severity of cognitive impairment was not assessed by the owner, as it is in our questionnaire, but a pre-established score was arbitrarily assigned to each item. These authors showed a correlation between their dementia score and several brain lesions, including amyloid. In contrast, we did not find a correlation between plasma $\mathrm{A} \beta$ peptide levels and any cognitive score in our aged dogs (CU and CI groups). However, if we considered only the $\mathrm{CU}$ and $\mathrm{mCI}$ animals, plasma $A \beta 1-42$ concentrations and the $A \beta 42 / 40$ ratio significantly correlated with TDS, RDS and the total number of affected items. These results are congruent with the idea that changes in $A \beta$ blood levels could be an early marker for the onset of brain amyloid pathology and cognitive impairment. At more advanced stages, probably after development of extensive cerebral amyloid angiopathy, plasma peptide levels would not correlate with ongoing brain pathology and cognitive dysfunction [46, 48, 49]. Furthermore, in spite of the uncertainties of the veterinary clinical criterion standard, the AUC obtained for plasma $A \beta 1-42$ levels and the $A \beta 42 / 40$ ratio would allow for discrimination between $\mathrm{mCI}$ and $\mathrm{CU}$ dogs with a sensitivity and specificity close to, although still lower than, that considered suitable for most AD biomarkers. In our opinion, this is of the greatest interest because, from any practical point of view, it is at these early stages of $\mathrm{AD}$ when the diagnoses should be improved, and the canine model would be particularly useful in this context. 


\subsection{Conclusion}

These results show that plasma $A \beta 1-42$ and $A \beta 1-40$ levels differ as a function of age in dogs and relate to the level and severity of cognitive impairment. Younger animals showed higher plasma $A \beta 1-42$ and $A \beta 1-40$ than normal aged dogs, suggesting that plasma $A \beta$ levels may decrease as brain $A \beta$ deposition increases with age. High $A \beta 1-42$ and $A \beta 42 / 40$ levels were found in dogs suffering mild cognitive impairment, as compared to both severely impaired dogs and control subjects. These findings suggest that changes in plasma $A \beta 1-42$ levels in pet dogs during pathological aging might exhibit patterns similar to those previously reported for human MCI and AD.

\section{Acknowledgements}

Disclosure statements for the authors: PP, IM, and MS are employees at Araclon Biotech Ltd. AM-G and BR are supported by grants from Araclon Biotech to the University of Santiago and Zaragoza, respectively. GS, M-LS, SG-B and AV have no actual or potential conflict of interest. 


\section{References}

[1] D. Borras, I. Ferrer, M. Pumarola, Age-related changes in the brain of the dog. Vet. Pathol. 36 (1999) 202-211.

[2] K. Uchida, H. Nakayama, S. Tateyama, N. Goto, Immunohistochemical analysis of constituents of senile plaques and cerebro-vascular amyloid in aged dogs. J. Vet. Med. Sci. 54 (1992) 1023-1029.

[3] M.-A. Colle, J.-J. Hauw, F. Crespeau, T. Uchihara, H. Akiyama, F. Checler, P. Pageat, C. Duykaerts, Vascular and parenchymal Abeta deposition in the aging dog: correlation with behavior. Neurobiol. Aging 21 (2000) 695-704.

[4] J.E. Rofina, A.M. van Ederen, M.J. Toussaint, M. Secreve, S.A. van der, d.M. van, I, F.J. Van Eerdenburg, E. Gruys, Cognitive disturbances in old dogs suffering from the canine counterpart of Alzheimer's disease. Brain Res. 1069 (2006) 216-226.

[5] V. Bernedo, D. Insua, M.-L. Suárez, G. Santamarina, M. Sarasa, P. Pesini, Cortical beta-amyloid pathology in the dog is accompanied with loss of serotonergic neurons. J. Comp. Neurol. (2008) .

[6] E. Head, R. Torp, Insights into A[beta] and Presenilin from a Canine Model of Human Brain Aging. Neurobiol. Dis. 9 (2002) 1-10.

[7] E. Head, J. Liu, T.M. Hagen, B.A. Muggenburg, N.W. Milgram, B.N. Ames, C.W. Cotman, Oxidative damage increases with age in a canine model of human brain aging. J. Neurochem. 82 (2002) 375-381.

[8] D. Insua, M.-L. Suarez, G. Santamarina, M. Sarasa, P. Pesini, Dogs with canine counterpart of Alzheimer's disease lose noradrenergic neurons. Neurobiol. Aging 31 (2010) 625-635.

[9] M. Pugliese, M.C. Geloso, J.L. Carrasco, J. Mascort, F. Michetti, N. Mahy, Canine cognitive deficit correlates with diffuse plaque maturation and S100beta (-) astrocytosis but not with insulin cerebrospinal fluid level. Acta Neuropathol. (Berl). 111 (2006) 519528.

[10] C.T. Siwak-Tapp, E. Head, B.A. Muggenburg, N.W. Milgram, C.W. Cotman, Region specific neuron loss in the aged canine hippocampus is reduced by enrichment. Neurobiol. Aging 29 (2008) 39-50.

[11] A. Skoumalova, J. Rofina, Z. Schwippelova, E. Gruys, J. Wilhelm, The role of free radicals in canine counterpart of senile dementia of the Alzheimer type. Exp. Gerontol. 38 (2003) 711-719.

[12] M.Y. Su, E. Head, W.M. Brooks, Z. Wang, B.A. Muggenburg, G.E. Adam, R. Sutherland, C.W. Cotman, O. Nalcioglu, Magnetic resonance imaging of anatomic and vascular characteristics in a canine model of human aging. Neurobiol. Aging 19 (1998) 479-485.

[13] P.D. Tapp, C.T. Siwak, F.Q. Gao, J.Y. Chiou, S.E. Black, E. Head, B.A.

Muggenburg, C.W. Cotman, N.W. Milgram, M.Y. Su, Frontal Lobe Volume, Function, and $\beta$-Amyloid Pathology in a Canine Model of Aging. J. Neurosci 24 (2004) 82058213.

[14] E.M. Johnstone, M.O. Chaney, F.H. Norris, R. Pascual, S.P. Little, Conservation of the sequence of the Alzheimer's disease amyloid peptide in dog, polar bear and five 
other mammals by cross-species polymerase chain reaction analysis. Brain Res Mol. Brain Res 10 (1991) 299-305.

[15] L. Sarasa, C. Gallego, I. Monleón, A. Olvera, J. Canudas, M. Montañés, P. Pesini, M. Sarasa, Cloning, sequencing and expression in the dog of the main APP isoforms and some of the enzymes related with their processing. Neuroscience 171 (2008) 10911101.

[16] M. Sarasa, P. Pesini, Natural non-trasgenic animal models for research in Alzheimer's disease. Curr. Alzheimer Res 6 (2009) 171-178.

[17] C.W. Cotman, E. Head, The canine (dog) model of human aging and disease: dietary, environmental and immunotherapy approaches. J. Alzheimers. Dis. 15 (2008) 685-707.

[18] S. Heath. Behaviour problems in geriatric pet. In: D. Horwitz, D. Mills, S. Heath (Eds.), Manual of canine and feline behavioural medicine, British small animal veterinary association, Gloucester, 2002, pp. 109-118.

[19] W. Ruehl and B.L. Hart. Canine cognitive dysfunction. In: NH. Dodman, L. Schuster (Eds.), Psychopharmacology of animal behaviour disorders., Blackwell Science, Malden, 1998, pp. 283-304.

[20] G. Azkona, S. García-Belenguer, G. Chacón, B. Rosado, M. León, J. Palacio, Prevalence and risk factors of behavioural changes associated with age-related cognitive impairment in geriatric dogs. journal of small animal practice 50 (2009) 87-91.

[21] J.C. Neilson, B.L. Hart, K.D. Cliff, W.W. Ruehl, Prevalence of behavioral changes associated with age-related cognitive impairment in dogs. J Am. Vet. Med. Assoc. 218 (2001) 1787-1791.

[22] A. Assini, S. Cammarata, A. Vitali, M. Colucci, L. Giliberto, R. Borghi, M.L. Inglese, S. Volpe, S. Ratto, F. gna-Bricarelli, C. Baldo, A. Argusti, P. Odetti, A. Piccini, M. Tabaton, Plasma levels of amyloid beta-protein 42 are increased in women with mild cognitive impairment. Neurology 63 (2004) 828-831.

[23] I. Blasko, K. Jellinger, G. Kemmler, W. Krampla, S. Jungwirth, I. Wichart, K.H. Tragl, P. Fischer, Conversion from cognitive health to mild cognitive impairment and Alzheimer's disease: prediction by plasma amyloid beta 42, medial temporal lobe atrophy and homocysteine. Neurobiol. Aging 29 (2008) 1-11.

[24] S.A. Cosentino, Y. Stern, E. Sokolov, N. Scarmeas, J.J. Manly, M.X. Tang, N. Schupf, R.P. Mayeux, Plasma $\beta$-Amyloid and Cognitive Decline. Arch. Neurol. (2010) doi:10.1001/archneurol.2010.189.

[25] O.L. Lopez, L.H. Kuller, P.D. Mehta, J.T. Becker, H.M. Gach, R.A. Sweet, Y.F. Chang, R. Tracy, S.T. DeKosky, Plasma amyloid levels and the risk of AD in normal subjects in the Cardiovascular Health Study. Neurology 70 (2008) 1664-1671.

[26] R. Mayeux, L.S. Honig, M.X. Tang, J. Manly, Y. Stern, N. Schupf, P.D. Mehta, Plasma $A \beta 40$ and $A \beta 42$ and Alzheimer's disease: relation to age, mortality, and risk. Neurology 61 (2003) 1185-1190.

[27] P.D. Mehta, T. Pirttila, S.P. Mehta, E.A. Sersen, P.S. Aisen, H.M. Wisniewski, Plasma and cerebrospinal fluid levels of amyloid beta proteins 1-40 and 1-42 in Alzheimer disease. Arch. Neurol. 57 (2000) 100-105. 
[28] N. Schupf, M.X. Tang, H. Fukuyama, J. Manly, H. Andrews, P. Mehta, J. Ravetch, R. Mayeux, Peripheral A $\beta$ subspecies as risk biomarkers of Alzheimer's disease. Proc. Natl. Acad. Sci. U. S. A 105 (2008) 14052-14057.

[29] T. Sobow, M. Flirski, I. Kloszewska, P.P. Liberski, Plasma levels of alpha beta peptides are altered in amnestic mild cognitive impairment but not in sporadic Alzheimer's disease. Acta Neurobiol. Exp. (Wars. ) 65 (2005) 117-124.

[30] van Oijen M., A. Hofman, H.D. Soares, P.J. Koudstaal, M.M. Breteler, Plasma Abeta(1-40) and Abeta(1-42) and the risk of dementia: a prospective case-cohort study. Lancet Neurol. 5 (2006) 655-660.

[31] W. Xia, T. Yang, G. Shankar, I.M. Smith, Y. Shen, D.M. Walsh, D.J. Selkoe, A specific enzyme-linked immunosorbent assay for measuring beta-amyloid protein oligomers in human plasma and brain tissue of patients with Alzheimer disease. Arch. Neurol. 66 (2009) 190-199.

[32] K. Blennow, H. Hampel, M. Weiner, H. Zetterberg, Cerebrospinal fluid and plasma biomarkers in Alzheimer disease. Nat. Rev. Neurol. 6 (2010) 131-144 .

[33] S.H. Freeman, S. Raju, B.T. Hyman, M.P. Frosch, M.C. Irizarry, Plasma Abeta levels do not reflect brain Abeta levels. J Neuropathol. Exp. Neurol. 66 (2007) 264-271.

[34] N.R. Graff-Radford, J.E. Crook, J. Lucas, B.F. Boeve, D.S. Knopman, R.J. Ivnik, G.E. Smith, L.H. Younkin, R.C. Petersen, S.G. Younkin, Association of low plasma Abeta42/Abeta40 ratios with increased imminent risk for mild cognitive impairment and Alzheimer disease. Arch. Neurol. 64 (2007) 354-362.

[35] O. Hansson, H. Zetterberg, E. Vanmechelen, H. Vanderstichele, U. Andreasson, E. Londos, A. Wallin, L. Minthon, K. Blennow, Evaluation of plasma Abeta(40) and Abeta(42) as predictors of conversion to Alzheimer's disease in patients with mild cognitive impairment. Neurobiol. Aging 31 (2010) 357-367.

[36] J.C. Lambert, S. Schraen-Maschke, F. Richard, N. Fievet, O. Rouaud, C. Berr, J.F. Dartigues, C. Tzourio, A. Alperovitch, L. Buee, P. Amouyel, Association of plasma amyloid beta with risk of dementia: the prospective Three-City Study. Neurology 73 (2009) 847-853.

[37] P. Lewczuk, J. Kornhuber, E. Vanmechelen, O. Peters, I. Heuser, W. Maier, F. Jessen, K. Burger, H. Hampel, L. Frolich, F. Henn, P. Falkai, E. Ruther, H. Jahn, C. Luckhaus, R. Perneczky, K. Schmidtke, J. Schroder, H. Kessler, J. Pantel, H.J. Gertz, H. Vanderstichele, M.G. De, F. Shapiro, S. Wolf, M. Bibl, J. Wiltfang, Amyloid beta peptides in plasma in early diagnosis of Alzheimer's disease: A multicenter study with multiplexing. Exp. Neurol. (2009) doi:10.1016/j.expneurol.2009.07.024.

[38] E.S. Oh, J.C. Troncoso, S.M. Fangmark Tucker, Maximizing the potential of plasma amyloid-beta as a diagnostic biomarker for Alzheimer's disease.

Neuromolecular. Med. 10 (2008) 195-207.

[39] J. Sundelof, V. Giedraitis, M.C. Irizarry, J. Sundstrom, E. Ingelsson, E. Ronnemaa, J. Arnlov, M.D. Gunnarsson, B.T. Hyman, H. Basun, M. Ingelsson, L. Lannfelt, L. Kilander, Plasma beta amyloid and the risk of Alzheimer disease and dementia in elderly men: a prospective, population-based cohort study. Arch. Neurol. 65 (2008) 256-263.

[40] P. Pesini, M. Boada, P. Martínez-Lage, L. Tárraga, I. Monleón, V. Pérez-Grijalva, I. San-José, J. Porcel-Carbonel, A. Gutiérrez-Blanco, M. Sarasa, Differences in beta 
amyloid pool in blood discriminate between amnesic mild cognitive impairment patients and healthy controls. J. Nutr. Health Aging 13 (2009) 850.

[41] I. Bourdel-Marchasson, H. Laksir, E. Puget, Interpreting routine biochemistry in those aged over 65 years: a time for change. Maturitas 66 (2010) 39-45.

[42] G. Hayes, K. Mathews, G. Doig, S. Kruth, S. Boston, S. Nykamp, Z. Poljak, C. Dewey, The acute patient physiologic and laboratory evaluation (APPLE) score: a severity of illness stratification system for hospitalized dogs. J. Vet. Intern. Med. 24 (2010) 1034-1047.

[43] D.J. Selkoe, Alzheimer's disease: genes, proteins, and therapy. Physiol Rev. 81 (2001) 741-766.

[44] E. Head, V. Pop, F. Sarsoza, R. Kayed, T.L. Beckett, C.M. Studzinski, J.L. Tomic, C.G. Glabe, M.P. Murphy, Amyloid-beta peptide and oligomers in the brain and cerebrospinal fluid of aged canines. J. Alzheimers. Dis. 20 (2010) 637-646.

[45] G. DeMeyer, F. Shapiro, H. Vanderstichele, E. Vanmechelen, S. Engelborghs, P.P. De Deyn, E. Coart, O. Hansson, L. Minthon, H. Zetterberg, K. Blennow, L. Shaw, J.Q. Trojanowski, Diagnosis-independent Alzheimer disease biomarker signature in cognitively normal elderly people. Arch. Neurol. 67 (2010) 949-956.

[46] C.R. Jack, Jr., V.J. Lowe, S.D. Weigand, H.J. Wiste, M.L. Senjem, D.S. Knopman, M.M. Shiung, J.L. Gunter, B.F. Boeve, B.J. Kemp, M. Weiner, R.C. Petersen, Serial PIB and MRI in normal, mild cognitive impairment and Alzheimer's disease: implications for sequence of pathological events in Alzheimer's disease. Brain 132 (2009) 1355-1365.

[47] A.M. Fagan, C.M. Roe, C. Xiong, M.A. Mintun, J.C. Morris, D.M. Holtzman, Cerebrospinal fluid tau/beta-amyloid(42) ratio as a prediction of cognitive decline in nondemented older adults. Arch. Neurol. 64 (2007) 343-349.

[48] G.B. Frisoni, N.C. Fox, C.R. Jack, Jr., P. Scheltens, P.M. Thompson, The clinical use of structural MRI in Alzheimer disease. Nat. Rev. Neurol. 6 (2010) 67-77.

[49] C.R. Jack, Jr., D.S. Knopman, W.J. Jagust, L.M. Shaw, P.S. Aisen, M.W. Weiner, R.C. Petersen, J.Q. Trojanowski, Hypothetical model of dynamic biomarkers of the Alzheimer's pathological cascade. Lancet Neurol. 9 (2010) 119-128.

[50] A.M. FaganD.M. Holtzman, Cerebrospinal fluid biomarkers of Alzheimer's disease. Biomark. Med. 4 (2010) 51-63.

[51] L.M. Shaw, H. Vanderstichele, M. Knapik-Czajka, C.M. Clark, P.S. Aisen, R.C. Petersen, K. Blennow, H. Soares, A. Simon, P. Lewczuk, R. Dean, E. Siemers, W. Potter, V.M. Lee, J.Q. Trojanowski, Cerebrospinal fluid biomarker signature in Alzheimer's disease neuroimaging initiative subjects. Ann. Neurol. 65 (2009) 403-413. 


\section{Figure legends}

Fig 1 Bar graphs for plasma $A \beta 1-42$ and $A \beta 1-40$ concentrations (in $\mathrm{pg} / \mathrm{ml}$ ) and for the $\mathrm{A} \beta 42 / 40$ ratio (multiplied by 100 for clarity of the graph). In $\mathrm{A}$, the four groups are represented. In B, the CI group was split into $\mathrm{mCI}(\mathrm{n}=21)$ and $\mathrm{SCI}(\mathrm{n}=17)$, and the same three parameters were compared with the CU group. Asterisks in A represent significance compared to the CU group and in B represent significance compared to the mCI group. $* * *$ or $* * *$ means $p<0.05,0.01$ or 0.001 , respectively. $\neq$ (in A) means $p<$ 0.05 compared to $\mathrm{YG}$.

Fig 2 A dot-plot for $\mathrm{A} \beta 1-42$ levels in $\mathrm{pg} / \mathrm{ml}(\mathrm{A})$ and the $\mathrm{A} \beta 42 / 40$ ratio (B) in $\mathrm{CU}, \mathrm{mCI}$ and sCI dogs. Numbers beside * indicate the value for outliers, which are not represented at the same scale of the ordinate axis for clarity of the graph. A considerable overlap was seen for these two parameters between CU and CI dogs. However, plasma concentrations of $A \beta 1-42$ and the $A \beta 42 / 40$ ratio, as shown by their ROC curves in $C$ and $\mathrm{D}$, respectively, allow for discrimination between $\mathrm{CU}$ and $\mathrm{mCI}$ dogs with sensitivity and specificity similar to those considered suitable for most diagnostic tests (AUC $\geq$ $0.85)$. 
Table 1. Demographic data in the studied canine population.

\begin{tabular}{|c|c|c|c|c|c|c|c|}
\hline \multicolumn{2}{|c|}{ Group } & Males & Females & Neutered & $\begin{array}{c}\text { Age } \\
\text { (months) }\end{array}$ & $\begin{array}{c}\text { Weight } \\
(\mathrm{Kg})\end{array}$ & $\begin{array}{c}\text { Body condition } \\
(1-5)^{\dagger}\end{array}$ \\
\hline & & \multicolumn{2}{|c|}{$(\%)$} & $(\%)$ & Mean \pm SD & Mean \pm SD & Mean \pm SD \\
\hline YG & $(n=9)$ & 55.6 & 44.4 & 33.3 & $31.1 \pm 17.7$ & $11.8 \pm 5.7$ & $3.2 \pm 0.4$ \\
\hline MA & $(n=10)$ & 30.0 & 70.0 & 40.0 & $83.2 \pm 16.7$ & $12.8 \pm 10.6$ & $3.2 \pm 0.4$ \\
\hline CU & $(n=31)$ & 48.4 & 51.6 & 41.9 & $146.4 \pm 35.2$ & $12.2 \pm 7.7$ & $3.5 \pm 0.8$ \\
\hline \multirow[t]{2}{*}{ CI } & $(n=38)$ & 60.5 & 39.5 & 42.1 & $152.6 \pm 25.1$ & $14.8 \pm 9.2$ & $3.5 \pm 0.6$ \\
\hline & & \multicolumn{2}{|c|}{$p=0.35^{\mathrm{a}}$} & $p=0.97^{\mathrm{a}}$ & $p=0.15^{\mathrm{b}}$ & $p=0.59^{c}$ & $p=0.42^{\mathrm{a}}$ \\
\hline
\end{tabular}

YG: young; MA: middle aged; CU: cognitively unimpaired aged; CI: cognitively impaired aged. 'Body condition scale: 1(too thin) - 3(thin) - 3(ideal) - 4(heavy) - 5(too heavy).

${ }^{\mathrm{a}}$ Chi-square test, ${ }^{\mathrm{b}}$ Mann-Whitney U tes tbetween CU and CI groups, ${ }^{\mathrm{c}}$ Kruskal-Wallis test. 
Table 2. Frequency distribution (percentage) of impaired categories and items in each group.

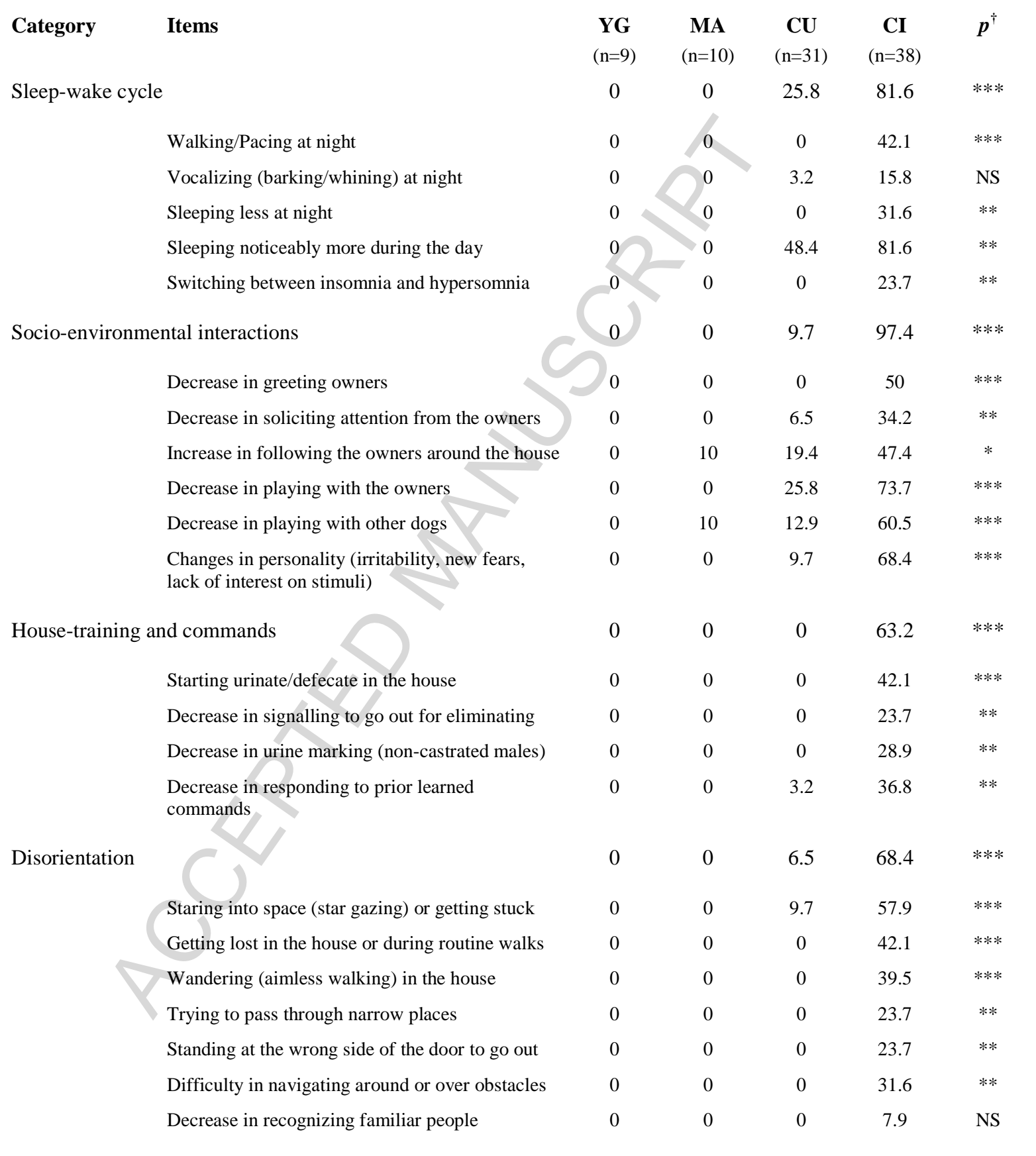

YG: Young; MA: Middle aged; CU: cognitively unimpaired aged; CI: cognitively impaired aged. ${ }^{\dagger} p$ values corresponding to statistical differences between groups 3 and $4 .{ }^{*}, p<0.05$; **, $p<0.01$; ***, $p<0.001$; NS, Nonsignificant difference. 
Table 3. Amyloid $\beta$-peptides concentrations (pg/ $\mu \mathrm{l})$ and A $\beta 42 / 40$ ratios in each group of study.

\begin{tabular}{lccc} 
Group & $\mathbf{A} \boldsymbol{\beta 4 0}$ & $\mathbf{A} \boldsymbol{\beta 4 2}$ & $\mathbf{A} \boldsymbol{\beta 4 2 / 4 0}$ \\
\cline { 2 - 2 } & $88.7 \pm 35.3^{\mathrm{ma}, \mathrm{cu}}$ & $59.2 \pm 58.6^{\mathrm{cu}}$ & $0.59 \pm 0.38^{\mathrm{CU}}$ \\
YA & $61.5 \pm 19.4$ & $31.4 \pm 32.5$ & $0.44 \pm 0.29$ \\
CU & $64.7 \pm 24.1$ & $23.3 \pm 12.0$ & $0.35 \pm 0.20$ \\
CI & $79.1 \pm 33.0$ & $46.1 \pm 53.7^{\mathrm{cu}}$ & $0.52 \pm 0.35^{\mathrm{cu}}$ \\
\hline
\end{tabular}

YG: young; MA: middle aged; CU: cognitively unimpaired aged; CI: cognitively impaired aged. Different letters indicate significant differences between groups (capital letters: $p<0.001$; lower case letters: $p<0.05)$. 
Table 4. Amyloid $\beta$-peptides concentrations $(\mathrm{pg} / \mu \mathrm{l})$ and $\mathrm{A} \beta 42 / 40$ ratios in the aged groups.

\begin{tabular}{lccc}
$\begin{array}{c}\text { Cognitive } \\
\text { status }\end{array}$ & $\mathbf{A} \boldsymbol{\beta 4 0}$ & $\mathbf{A} \boldsymbol{\beta 4 2}$ & $\mathbf{A \beta 4 2 / 4 0}$ \\
\cline { 2 - 4 } & & Mean $\pm \mathrm{SD}$ & \\
$\mathbf{C U}$ & $64.7 \pm 24.1$ & $23.3 \pm 12.0^{\mathrm{M}}$ & $0.35 \pm 0.20^{\mathrm{M}}$ \\
$\mathbf{m C I}$ & $82.1 \pm 38.8$ & $58.3 \pm 65.5$ & $0.65 \pm 0.37$ \\
SCI & $75.3 \pm 24.7$ & $31.1 \pm 29.5^{\mathrm{m}}$ & $0.37 \pm 0.26^{\mathrm{m}}$
\end{tabular}

CU: cognitively unimpaired; mCI: mild cognitive impairment; sCI: severe cognitive impairment. Letters $\mathrm{m} / \mathrm{M}$ indicate significant differences with regard to the $\mathrm{mCI}$ group (capital letters: $p<0.01$; lower case letters: $p<0.05$ ). 


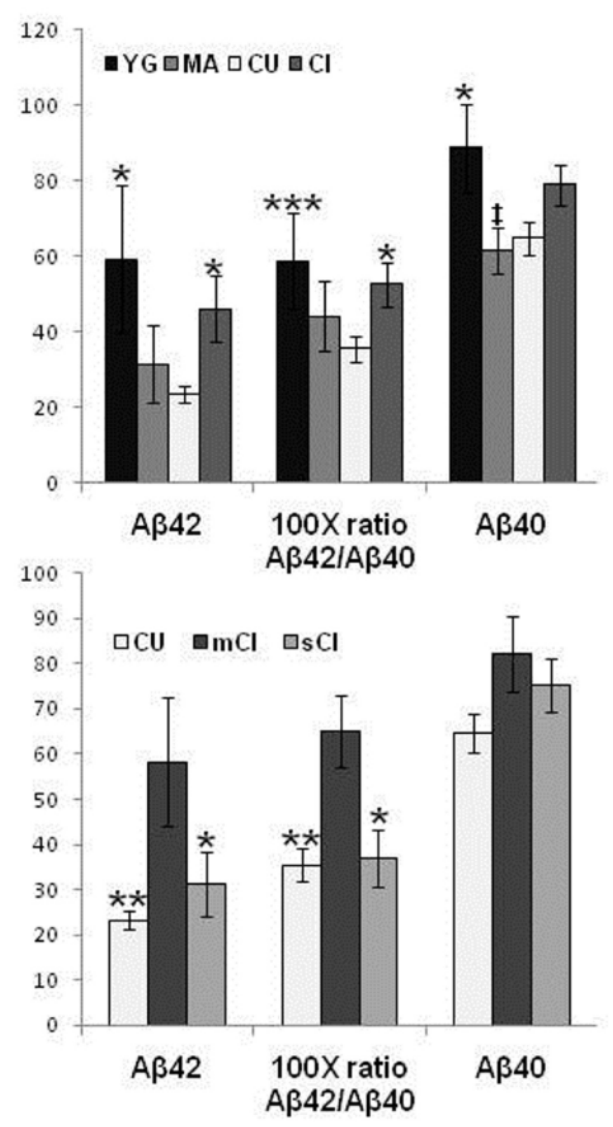

Fig 1 

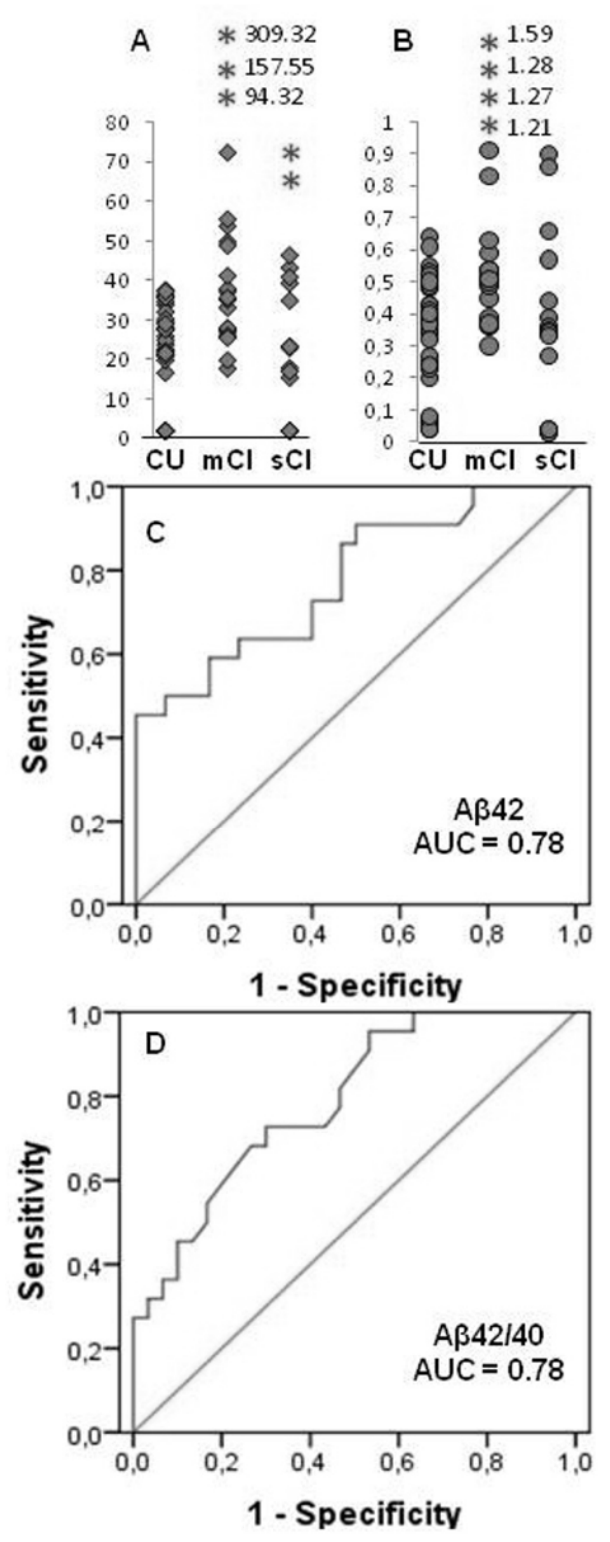

Fig 2 


\section{Research highlights.}

$1^{\circ}$ ) plasma $A \beta$ was analyzed for the first time in relation to age in a pet dog population. $2^{\circ}$ ) aged dogs with cognitive dysfunction have higher $A \beta 42$ plasma levels than controls. $3^{\circ}$ ) A $\beta 42$ levels were higher in mildly cognitive impaired than in severely affected dogs. $4^{\circ}$ ) plasma $A \beta 42$ could be an early biomarker for cognitive dysfunction in aged dogs. $5^{\circ}$ ) canine cognitive dysfunction syndrome appears as an excellent natural model for early $\mathrm{AD}$. 